\title{
STUDY OF WARM ISCHEMIA FOLLOWED BY REPERFUSION ON A LOWER LIMB MODEL IN RATS: EFFECT OF ALLOPURINOL AND STREPTOKINASE
}

\author{
Marcelo Sacramento Cunha, Jose Carlos Faes da Silva, Hugo Alberto Nakamoto, \\ and Marcus Castro Ferreira
}

Cunha MS, Silva JCF da, Nakamoto HA, Ferreira MC. Study of warm ischemia followed by reperfusion on a lower limb model in rats: effect of allopurinol and streptokinase. Clinics. 2005;60(3):213-20.

Prolonged tissue ischemia leads to changes in microcirculation and production of oxygen free radicals. The event eventually responsible for tissue death is the no-reflow phenomenon and its management is a challenge for the surgeon dealing with replantation or transplantation. We introduce a model of warm ischemia and reperfusion of the lower limb of rats with which we studied the effect of allopurinol and streptokinase.

METHOD: Section of the lower limb with preservation of vessels and nerves was performed in 110 rats. Femoral vessels clamped for periods of $0,2,4,6$, and 8 hours of ischemia were allowed to reperfuse (groups M0, M2, M4, M6, and M8 respectively). Other groups, E1, E2, and E3, received streptokinase, allopurinol, or a combination of the two drugs after 6 hours of ischemia.

RESULTS: Viability rates of the ischemic limbs after 7 days were 100\% (M0), 80\% (M2), 63.6\% (M4), 50\% (M6), and 20\% (M8). In the experimental groups, E1, E2, and E3, viability rates were 67\% (E1), 70\% (E2), and 70\% (E3). Groups M0, M2, M4, M6, and M8 differed among themselves except for groups M4 and M6. Group E1 had a higher rate of limb viability than M6 (control group) but not than M4. Groups E1, E2 and E3 had higher rates of limb viability than M6 but not than M2 or M4.

DISCUSSION: The results suggest that increased viability of limbs after 6 hours of ischemia occurs when allopurinol or streptokinase is used. The combination of the two drugs does not appear to produce any additional effect.

KEYWORDS: Warm ischemia. No-reflow phenomenon. Free radicals. Rat limb.

Replantation of extremities after amputation or major trauma is not always successful, and the most important factor is the time elapsed from the beginning of ischemia. Viability and final functional result depend on the prevention of damaging effects of anoxia. The involved tissues have different resistances to anoxia. Skeletal muscle is the least tolerant to ischemia and the anatomical, metabolic, and pathophysiological effects having been thoroughly

Plastic Surgery Discipline, and Laboratory of Plastic Surgery and Microsurgery (LIM04), Faculty of Medicine, University of São Paulo - São Paulo/SP, Brazil.

E-mail: zefaes@osite.com.br

Received for publication on November 05, 2004.

Accepted for publication on February 24, 2005. studied. ${ }^{1-3}$ Maintenance of muscle viability is critical for the success of replantation.

The effort to improve limb viability has led authors to introduce different models to study ischemic limb perfusion and the effect of different drugs on survival rates. ${ }^{4}$ No consensus exists regarding the best model for studying ischemia, and limb survival rates differ from model to model. Successful replantations with longer periods of ischemia have been reported. ${ }^{1}$

Although microsurgical anastomosis is critical, the distal capillary circulation is equally important in terms of the viability of microsurgical flaps and replanted limbs. Prolonged ischemia followed by reperfusion produces irreversible damage to microcirculation, leading to obstruction of blood flow to peripheral tissues. These alterations to mi- 
crocirculation constitute the no-reflow phenomenon. ${ }^{3,5-9}$ Obstruction is progressive, with thrombus formation in the microcirculation, platelet aggregation, and tissue edema. Irreversible damage and loss of limb or of microsurgical flap can result. .,8,10,11 $^{2}$

The possible role of oxygen free radicals in the pathogenesis of tissue lesions after reperfusion has been studied, as has the use of pharmacological agents to prevent this phenomenon. ${ }^{12,13}$ Encouraging results have been obtained using antioxidants, as well as a number of other drugs and agents in different tissues. ${ }^{5,14,15}$ The superoxide radical is created in all aerobic organisms under various conditions and causes peroxidation of membranes and proteins resulting in tissue destruction and irreversible cell injury. ${ }^{2,7,16,17}$

Vascular thrombosis is a significant complication in microsurgery. There are several causes for thrombosis, all of which may lead to failure of a microvascular anastomosis. ${ }^{18,19}$ Some factors are inherent to replanted tissues, while others depend on surgical technique. Tissue trauma has been recognized as the main cause of limb loss. ${ }^{20}$ Various anti-thrombotic and anti-inflammatory drugs have been studied in experimental flaps in trying to prevent vascular thrombosis. ${ }^{19,21}$

An animal model using rats was developed in the Laboratory for Experimental Microsurgery at the Fac. Med. Univ. São Paulo to determine the maximum ischemic period tissues can sustain and the influence of different drugs on the prevention of deleterious effects of warm ischemia and reperfusion. This paper presents this experimental model of warm ischemia and reperfusion and its use in assessing the effect of allopurinol and streptokinase on the survival of the extremities.

\section{METHOD}

This project was approved by the Institutional Ethics Committee, and follows the NIH guidelines for animal experiments.

One hundred and ten male Wistar rats ranging in age from 16 to 20 weeks and weighing between 290 and $400 \mathrm{~g}$ were used. The animals were maintained in individual cages with food and water ad libitum, a light/dark period of 12/ 12 hours, and a room temperature of $23^{\circ} \mathrm{C}$. The same surgeon performed all surgical procedures.

\section{Surgical procedure}

The animals were anesthetized using intraperitoneal sodium pentobarbital $(50 \mathrm{mg} / \mathrm{kg})$ injection. A subtotal amputation of the right posterior limb was accomplished, preserving the femoral vessels and the sciatic nerve.
A circular incision in the mid-portion of the thigh was performed around the entire circumference including skin and subcutaneous tissue. Femoral vessels and nerve were dissected using a surgical microscope (Karl Kaps model D35614 ASSLAR - 16X magnification), and muscles of the mid-third thigh were severed, but the sciatic nerve was identified and kept intact. Osteotomy of the mid-third of the femur was performed with a manual saw (Fig. 1). Those tissues were immediately reconstructed, starting with the bone, by intramedullary fixation of the femur with a $2 \mathrm{~cm}$ needle segment and instant cyanoacrylate ester glue. Horizontal $\mathrm{U}$ stitches of 5-0 nylon were used for the muscle synthesis.

An atraumatic microvascular clamp was applied to right femoral vessels before the emergence of the superficial caudal epigastric vessels, avoiding the inclusion of the femoral nerve (Fig. 2). A negative milking test certified interruption of arterial and venous flow, and ischemia was considered to be complete.

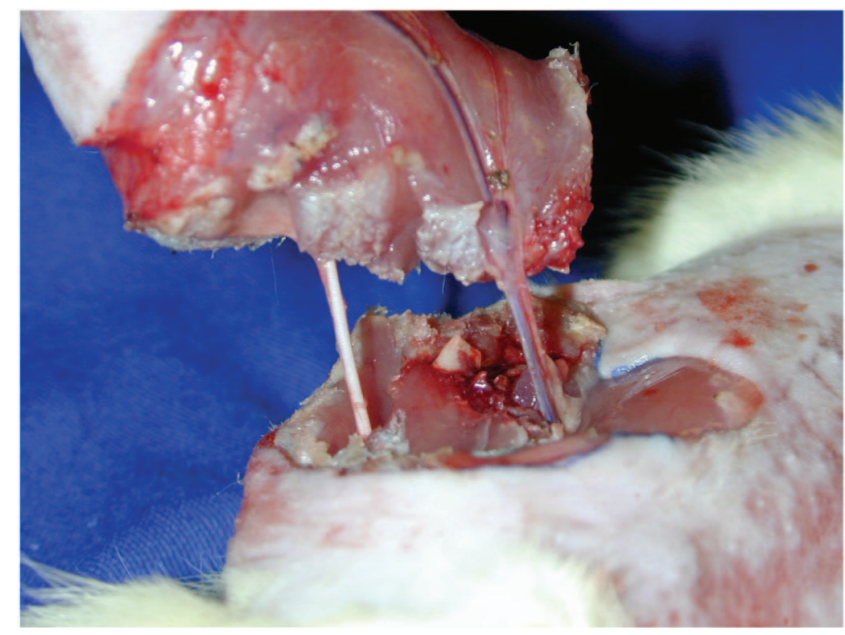

Figure 1 - Amputated limb with preservation of vessels and nerves.

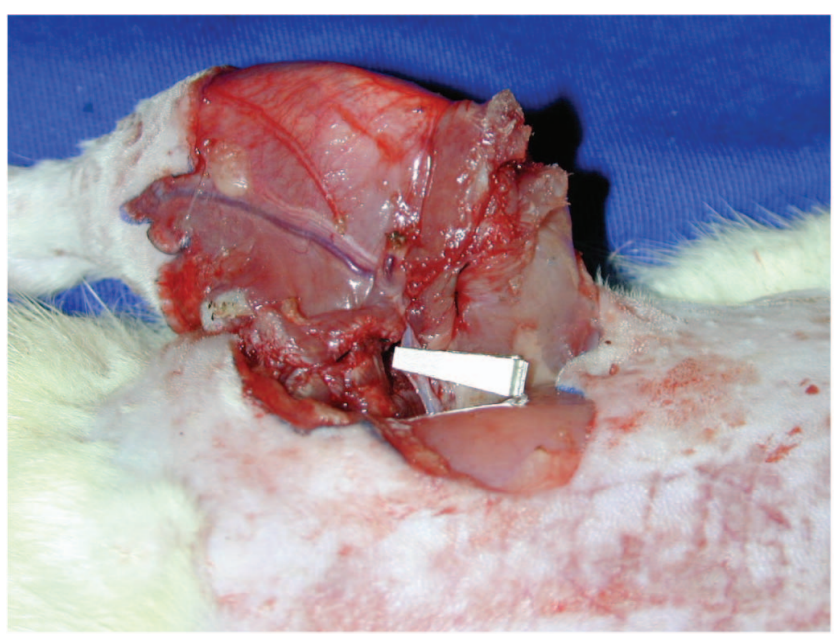

Figure 2 - Limb undergoing replantation and positioning of the microvascular clamp 
Fluid volume was replaced postoperatively by a subcutaneous injection of $50 \mathrm{~mL} / \mathrm{kg}$ of saline. The mean time for subtotal amputation and replantation was 33 minutes (range, 15-45 minutes). Twenty-one animals died during surgery or within 7 postoperative days, a perioperative mortality rate of $19 \%$. This mortality rate was similar to that experienced by Ferreira et al. ${ }^{1}(25.5 \%)$ and Shapiro ${ }^{22}$ et al. (15.4\%).

\section{Period of warm ischemia}

The animals were submitted to different times of warm ischemia after the vessels were clamped. During this period they were allowed to recover in individual cages at a room temperature of $25^{\circ} \mathrm{C}$, achieved using a $45 \mathrm{~W}$ and $127 \mathrm{~V}$ halogen lamp that was maintained $30 \mathrm{~cm}$ from the cage.

\section{Reperfusion}

At the end of the ischemic period, rats were reanesthetized. Dissection of the left femoral vessels and their branches was performed, a needle (29G) was inserted in the superficial caudal epigastric vein, $1 \mathrm{~mL}$ of saline, streptokinase, allopurinol, or streptokinase/alopurinol was injected, and the vascular clamp was removed.

Patency of the femoral vessels was confirmed by a positive milking test and absence of thrombi. The presence of thrombi and absence of flow in femoral vessels excluded the animal from the experiment.

\section{Groups}

The animals were divided into 5 model groups with 10 to 12 rats each that were submitted to ischemic periods of 0, 2, 4, 6, and 8 hours (M0, M2, M4, M6, and M8, respectively). It was determined that 6 hours of warm ischemia (M6) would be used as the control for the experimental groups. Three experimental groups with 10 or 12 animals per group were submitted to 6 hours of ischemia and received intravenous solutions of streptokinase, allopurinol or streptokinase/allopurinol (E1, E2, and E3, respectively) after 6 hours and immediately before the vascular clamp was removed (Table 1).

Allopurinol was diluted in $1 \mathrm{~N}$ sodium hydroxide until it fully dissolved. Hydrochloric acid (1N) was added to this alkaline solution until the start of allopurinol precipitation , indicating the minimum $\mathrm{pH}$ for solubility. A final drop of $1 \mathrm{~N}$ sodium hydroxide was used to redissolve the precipitate, and water was added to obtain the necessary final volume. One $\mathrm{mL}$ of the resulting solution contained $45 \mathrm{mg} / \mathrm{kg}$ of allopurinol (Allopurinolâ__Sigma Aldrich).

The streptokinase solution used contained 20000 IU/
Table 1 - Groups, number of animals, ischemic period, and solutions.

\begin{tabular}{llll}
\hline Groups & $\mathrm{N}$ & Ischemic period & Solutions \\
\hline M0 & 10 & $0 \mathrm{~h}$ & Saline \\
M2 & 10 & $2 \mathrm{~h}$ & Saline \\
M4 & 11 & $4 \mathrm{~h}$ & Saline \\
M6 & 10 & $6 \mathrm{~h}$ & Saline \\
M8 & 10 & $8 \mathrm{~h}$ & Saline \\
E1 & 12 & $6 \mathrm{~h}$ & Streptokinase* \\
E2 & 10 & $6 \mathrm{~h}$ & Allopurinol** \\
E3 & 10 & $6 \mathrm{~h}$ & Streptokinase/Allopurinol \\
\hline
\end{tabular}

*solution containing $20000 \mathrm{IU} / \mathrm{kg}$ of streptokinase diluted in $9 \%$ saline. (Streptase ${ }^{\circledR} 1500000$ IU-Hoeschst Marion Roussel)

**solution containing $45 \mathrm{mg} / \mathrm{kg}$ of allopurinol. (Allopurinol ${ }^{\circledR}$ —Sigma Aldrich)

$\mathrm{kg}$ of streptokinase (Streptase ${ }^{\hat{a}} 1500000$ IU-Hoeschst Marion Roussel) diluted in $1 \mathrm{ml}$ of $0.9 \%$ saline.

\section{Analysis of limb viability}

The animals were observed daily over a 7-day period. Limb viability was determined by clinical examination as an all-or-nothing response. A nonviable limb was defined by total limb necrosis. A viable limb was defined by total limb survival or total survival with partial necrosis of the skin near the suture with viable underlying muscle and normal hair growth.

Results were converted into percentage of limb viability per group. The groups were compared among themselves and analyzed using the chi-square test. The level of significance was set at $5 \%(P<.05)$.

\section{RESULTS}

\section{Groups}

Group M0 was submitted to 0 hours of ischemia and displayed a $100 \%$ limb viability rate (LVR). The LVR of the groups progressed as follows: M2, 80\%; M4, 64\%; M6, $50 \%$; and M8, 20\%. Differences between groups M0 vs. M2, M2 vs. M4, and M6 vs. M8 were statistically significant. The difference between groups M4 vs. M6 was not statistically significant.

After 6 hours of ischemia, group E1 (streptokinase) displayed an LVR of $67 \%$, which was statistically different from that of group M6 (6 hours and no drug) $(P<.05)$. No statistical difference was observed in the VLR rate between groups E1 and M4 (4 hours and no drug).

Group E2 (allopurinol) progressed with an LVR of $70 \%$ that was statistically different from that of group M6 $(P<$ $.05)$, but not from M2 or M4.

The association of allopurinol and streptokinase (E3) 
had an LVR of $70 \%$ and was statistically different from that of M6 $(P<.05)$. No statistical difference was observed between $\mathrm{E} 3$ and $\mathrm{M} 2$ or M4.

Differences among groups E1, E2, and E3 were not statistically significant.

Fig. 3 and 4 (graphs)

\section{DISCUSSION}

A variety of causes have been proposed for the noreflow phenomenon. Ames et al., ${ }^{7}$ in 1968, first described a no-reflow phenomenon in areas of ischemic brain. Miller et al. ${ }^{23}$ observed that arteriovenous shuntings occurred in replanted limbs, and this could also reduce blood flow. May et al. ${ }^{6}$ mentioned that stasis and loss of intravascular fluid with consequent exposure of subintimal collagen could lead to thrombosis after replantation. Urbaniak et al. ${ }^{24}$ classified the multiple factors responsible for the no-reflow phenomenon into 3 groups: ischemia, injury to the vascular intima, and systemic and local responses. This triad leads to histological and metabolic changes in the microcirculation that include vasoconstriction of arterioles, endothelial

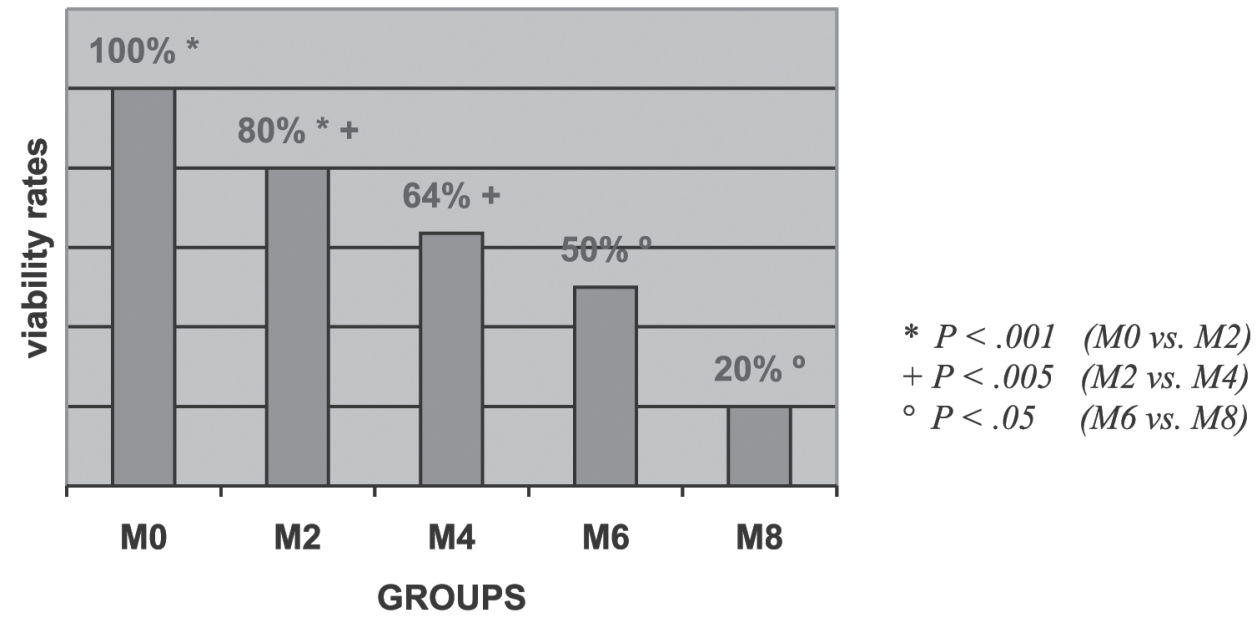

Figure 3 - Model groups. Statistically significant differences occurred between every consecutive pair, except M4 vs. M6.

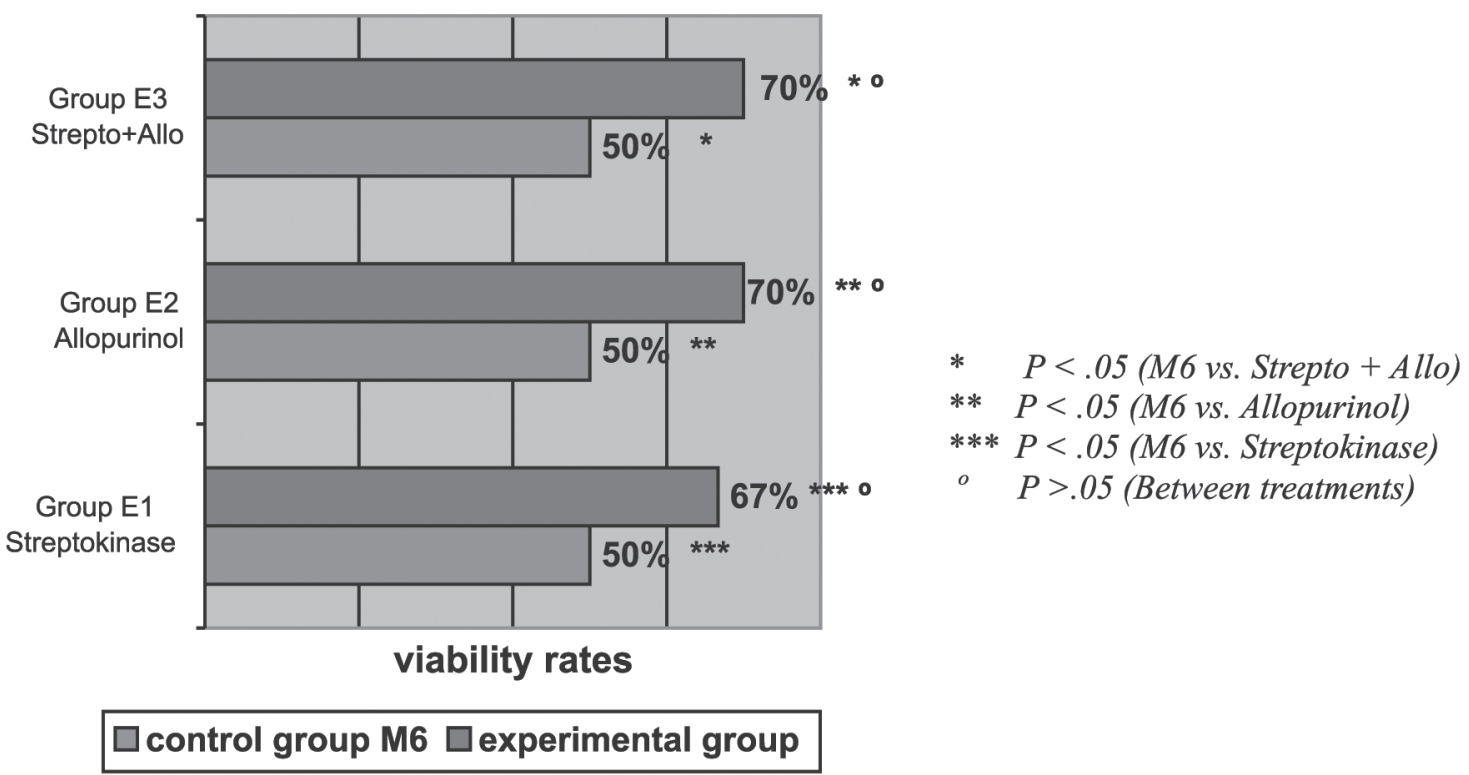

Figure 4 - Experimental groups. Streptokinase and Allopurinol viability rates. The combination produced no further improvement. 
edema, regional blood stasis, adhesion and migration of leukocytes, focal hemorrhage, platelet aggregation, production of oxygen free radicals, and acidosis.

Several experimental models have been developed to study this phenomenon. Stock et al. ${ }^{25}$ observed irreversible metabolic changes after 4 hours of ischemia of rat hind limbs. Swartz et al. ${ }^{26}$ reported $100 \%$ necrosis of rat hind limbs submitted to 6 hours of ischemia.

Zdeblick et al. ${ }^{27}$ studied replanted posterior rat limbs after several hours of ischemia and observed that limb viability exhibited an all-or-nothing response. After 2 or 3 hours of ischemia, viability rates were $100 \%$, after 4 hours the viability rate dropped to $50 \%$, and after 6 hours, $20 \%$. Edwards et al. ${ }^{28}$ also observed an all-or-nothing response in survival of rat hind limbs after replantation. The limbs were submitted to warm ischemia for 5 hours and the resulting LVR was $50 \%$. Concannon et al. ${ }^{29}$ obtained an LVR of $30 \%$ in posterior rat limbs submitted to 6 hours of warm ischemia and also observed an all-or-nothing response. Olivas et al. ${ }^{30}$ studied ischemia of the rat's cremaster muscle and observed that 7 or 8 hours of ischemia is the critical time for reversibility of reperfusion injuries in muscles.

The operative procedure in the present study consisted of subtotal hind limb amputation, keeping intact the vascular pedicle and nerve, a model which is similar to that used by Concannon et al. ${ }^{29}$ Keeping the vascular pedicle intact avoided the need for microvascular anastomosis and a new variable to be controled. ${ }^{22}$ The intact sciatic nerve prevented loss of sensibility and limb autophagia. which was only observed after the fourth postoperative day when there was necrosis of the limb. Concannon et al. ${ }^{29}$ described autophagia in viable and nonviable limbs with nerve injury.

Body fluid volume was replaced with $50 \mathrm{~mL} / \mathrm{kg}$ of saline. Blood loss via bone marrow in intramedullary fixation was reported as cause of death by Ferreira et al. ${ }^{1}$ Instant glue was used in this study for bone synthesis so as to avoid blood loss through the bone marrow.

In order to determine the critical time of ischemia, 5 groups were compared, ranging from immediate reperfusion to 8 hours, and in accordance with reported data, and an all-or-nothing response was recorded. The results evidenced a negative correlation between ischemic time and viability, therefore conferring reliability to the ischemia model.

\section{Effect of streptokinase}

Microvascular thrombosis is an important component of the no-reflow phenomenon. Blood stasis, endothelial ischemic injury, and exposure of the subendothelium activate the coagulation cascade and lead to formation of fibrin and platelet aggregation. Fibrinolytic drugs have been used in microsurgery as prophylaxis for preventing thrombosis of anastomosis. Urokinase, heparin, and prostaglandin E1 were part of the replantation protocol of Yamano ${ }^{31}$ and of Fukui \& Tamai. ${ }^{32}$ Vertos \& Tsavissis ${ }^{18}$ have used streptokinase and low molecular weight dextran routinely after replants. Fibrinolytic drugs can also be employed therapeutically to reduce the effects of ischemia injury. Their effectiveness has been shown in clinical treatment of various thrombotic pathologies, such as acute coronary arterial thrombosis, deep venous thrombosis, and pulmonary thromboembolism.

The role of thrombolytic agents in preserving viability in microsurgical flaps and replants is not fully established. A number of drugs have been tested with controversial results. More recently, streptokinase and rt-PA have been successfully used in replants and in experimental models of thrombosis. ${ }^{19}$

In this study, group E1 received an intravenous dose of $20,000 \mathrm{IU} / \mathrm{kg}$ of streptokinase after 6 hours of warm ischemia. This dose was based on those used clinically for systemic fibrinolysis and was also used by Busnardo et al. ${ }^{19}$ to study thrombosis in microsurgical anastomosis.

The LVR after streptokinase (67\%) was better and significantly different from the control group M6 (50\%). This result suggests that limbs submitted to 6 hours of ischemia and treated with streptokinase were protected compared to controls.

\section{Effect of allopurinol}

There are several references regarding the benefits of allopurinol and other antioxidants in ischemic models in fasciocutaneous flaps in rats and pigs. ${ }^{5,9,14,29}$

In this study, group E2 underwent limb ischemia for 6 hours and was treated with $45 \mathrm{mg} / \mathrm{kg}$ of intravenous allopurinol. Concannon et al. ${ }^{29}$ also used this dose and administration route.

The LVR of the allopurinol group (70\%) was significantly higher than that of group M6 (50\%). This data suggests that 6-hour ischemic limbs treated with allopurinol were protected compared to controls.

No statistical difference was found between groups E2 (70\%) and E3 (70\%), implying that there was no additional benefit from using a combined streptokinase-allopurinol treatment.

These data are similar to results found by Concannon et al. ${ }^{29}$ in which a viability rate of $60 \%$ was observed in 6hour ischemic rat limbs after administration of allopurinol. Ferrari et al..$^{33}$ noticed a reduction in compartmental pressure of amputated rat limbs with various ischemic times and administration of allopurinol. 
In summary, the proposed rat hind limb experimental model is simple, and it has a low rate of complications and mortality. It is reliable and suitable for studying ischemia, reperfusion, and the no-reflow phenomenon with an all-ornothing response.

This report demonstrated that viability rates of limbs after 6 hours of ischemia increased from $50 \%$ to $64 \%$ with streptokinase administration and to $70 \%$ with allopurinol. No additional effect was obtained with the combination of these drugs.
In summary, the proposed rat hind limb experimental model is simple, and it has a low rate of complications and mortality. It is reliable and suitable for studying ischemia, reperfusion, and the no-reflow phenomenon with an all-ornothing response.

This report demonstrated that viability rates of limbs after 6 hours of ischemia increased from 50\% to $64 \%$ with streptokinase administration and to $70 \%$ with allopurinol. No additional effect was obtained with the combination of these drugs.
Cunha MS, Silva JCF da, Nakamoto HA, Ferreira MC. Estudo da isquemia quente e reperfusão em membro inferior de ratos: efeito do allopurinol e estreptokinase. Clinics. 2005;60(3):213-20.

A isquemia prolongada dos tecidos leva a alterações na microcirculação e liberação de radicais livres do oxigênio, evento que pode resultar na morte do tecido, conhecido como fenômeno de não reperfusão. Um modelo em ratos de isquemia quente e reperfusão do membro posterior é proposto, e os efeitos dos fármacos alopurinol e estreptoquinase foram estudados.
MÉTODO: Secção do membro posterior com preservação dos vasos e nervos foi realizada em 110 ratos. O pinçamento vascular e posterior reperfusão após isquemia quente de 0 , 2, 4, 6 e 8 horas formou os grupos M0, M2, M4, M6 e M8 respectivamente. Outros grupos E1, E2 e E3 receberam, respectivamente, alopurinol, estreptoquinase e a combinação de ambas as drogas, após seis horas de isquemia.

RESULTADOS: As taxas de viabilidade dos membros isquêmicos, observadas após sete dias foram: M0 - 100\%, M2 - 80\% ,M4 - 64\%,M6 - 50\% e M8 - 20\%. As taxas de viabilidade dos grupos experimentais foram $67 \%$ (E1), 70\%(E2) e 70\%(E3). Os grupos M0, M2, M4, M6 e M8 fo- 
ram diferentes entre si exceto os grupos M4 e M6. E1, E2 e E3 resultaram em viabilidade de membros maiores que M6(controle), mas não em relação ao M2 e M4.

DISCUSSÃO: Os resultados sugerem um aumento da viabilidade de membros após 6 horas de isquemia quando utilizado os fármacos alopurinol ou estreptoquinase. A asso- ciação de estreptoquinase e alopurinol não mostrou efeito adicional.

\section{UNITERMOS: Isquemia quente. Fenômeno de não reperfusão. Radicais livres. Membro de rato.}

\section{REFERENCES}

1. Ferreira MC, Leao PP. Reimplante experimental de membro com microcirurgia vascular. Rev Assoc Med Bras. 1977;23(1):3-6.

2. Siemionow $\mathrm{M}$, Arslan E. Ischemia/reperfusion injury: a review in relation to free tissue transfers. Microsurg. 2004;24:468-75.

3. Khiabani KT, Kerigan CL. Differing flow patterns between ischemically challenged flap skin and skeletal muscle: implications for salvage regimens. Plast Reconstr Surg. 2002;109:220-7.

4. Sapega AA, Heppenstall RB, Sokolow DP. The bioenergetics of preservation of limbs before replantation. J Bone Joint Surg. 1988;70(10):1500-13.

5. Prada FS, Arrunategui G, Alves MC, Ferreira MC, Zumiotti A. Effect of allopurinol, superoxide-oxidase, and hyperbaric oxygen on flap survive. Microsurg. 2002;22:352-60.

6. May JW, Chait LA, O'Brien B. The no-reflow phenomenon in experimental free flaps. Plast Reconstr Surg. 1978;61(2):256-67.

7. Ames A, Wrigth R, Kowoda M, Majno G. Cerebral ischemia. The no-reflow phenomenon. Am J Pathol. 1968;52:437-53.

8. Nanobashivili J, Neumayer C, Fuegl A. Ischemia/reperfusion injury of skeletal muscle: mechanisms, morphology, treatment strategies, and clinical applications. European Surg. 2002;34:83-9.

9. Pang CY, Forrest CR, Mounsey R. Pharmacologic intervention in ischemia-induced reperfusion injury in the skeletal muscle. Microsurg. 1993;14:176-82.

10. Nanobashivili J, Neumayer C, Fuegl A. Ischemia/reperfusion injury of skeletal muscle: plasma taurine as a measure of tissue damage. Surg. 2003;133(1):91-100

11. Huk I, Brovkovych V, Nanobashivili J. Bioflavonoid quercetin scavenges superoxide and increases nitric oxide concentration in ischemia-reperfusion injury: an experimental study. Br J Surg. 1998;85:1080-5.
12. Russell RC, Roth AC, Kucan JO. Reperfusion injury and oxygen free radicals. J Reconst Microsurg. 1989;5:79-89.

13. Klein MB, Chan PH, Chang J. Protective effects of superoxide dismutase against ischemia reperfusion injury: development and application of a transgenic animal model. Plast Reconstr Surg. 2003;111:(1)251-5.

14. Sunding BM, Hussein MA, Glasofer S. The role of allopurinol and deferoxamine in preventing pressure ulcers in pigs. Plast Reconstr Surg. 2000;105:1408-21.

15. Stewart JR, Blackwell WH, Crule SL. Prevention of myocardial ischaemia reperfusion injury with oxygen free radicals scavengers. Surg Forum. 1982,33:317

16. Manson PM, Anthenelli RM, Im MJ. The role of oxygen free radicals in ischemic tissue injury in island skin flaps. Ann Surg. 1983;198:87.

17. Aikens J, Dix TA. Perhydroxyl radical (HOO.) initiated lipid peroxidation. J Biol Chem. 1991;266:15091-98.

18. Vretos KA, Tsavissis AG. Antithrombotic and antiinflammatory drugs for protection of microvascular anastomosis. Actam Orthop Scand. 1995;66:48-9.

19. Busnardo F, Munhoz AM, Cunha MS. Eficácia da estreptoquinase sistêmica na taxa de patência vascular em um modelo de trombose arterial em ratos. In: Resumos do XXXIV Congresso Brasileiro de Cirurgia Plástica 1997; Brazil.

20. Khouri RK, Cooley BC, Kenna DM. Thrombosis of microvascular anastomoses in traumatized vessels: fibrin versus platelets. Plast Reconst Surg. 1990;86:110-7.

21. Lantieri LA, Ozbek MR, Deune EG. Prevention of microvascular thrombosis by topical application of recombinant tissue factor pathway inhibitor. Plast Reconstr Surg. 1996;97:587-94. 
22. Shapiro RI, Cerra FB. A model for reimplantation and transplantation of a complex organ: the rat hind limb. J Surg Research. 1978;24:501-6.

23. Miller SH, Lung RJ, Graham WP, Davis TS, Rusenas I. The acute effects of tourniquet ischemia on tissue and blood gas tensions in the primate limb. J Hand Surg. 1978;3:11.

24. Urbaniak JR, Seaber AV, Chen L. Assessment of ischemia and reperfusion injury. Clin Orthop. 1997;334:30-6.

25. Stock W, Bohn HJ, Isselhard W. Metabolic changes in rat skeletal muscle after acute arterial occlusion. Vasc Surg. 1971;5:249.

26. Swartz WM, Cha JM, Ambler M. Prolonged ischemia in the replanted rat leg: a biochemical and morphologic study with microvascular techniques. Surg Forum. 1976;27:565.

27. Zdeblick TA, Shaffer JW, Field GA. An ischemia-induced model of revascularization failure of replanted limbs. J Hand Surg. 1985;10A:125-31.
28. Edwards RJ, Im MJ, Hoopes JE. Effects of hyperbaric oxygen preservation on rat limb replantation: a preliminary report. Ann Plast Surg. 1991;27:31-5.

29. Concannon MJ, Dooley TW, Puckett CL. Improved survival in a replantation model containing ischemic muscle. Microsurg. $1991 ; 12: 18-22$.

30. Olivas TP, Saylor TF, Wong HP, Stephenson LL. Timing of microcirculatory injury from ischemia reperfusion. Plast Reconstr Surg. 2001;107:785.

31. Yamano Y. Replantation of fingertips. J Hand Surg. 1993;18:15762.

32. Fukui A, Tamai S. Present status of replantation in Japan. Microsurg. $1994 ; 15: 842-7$

33. Ferrari RP, Battiston B, Brunelli G. The role of allopurinol in preventing oxygen free radical injury to skeletal muscle and endothelial cells after ischemia-reperfusion. J Reconst Microsurg. 1996; $12: 447-50$. 